\title{
FEATURES OF FORMATION OF COMPETITIVENESS OF THE ENTERPRISES SPECIALIZING IN THE PRODUCTION OF BREAD AND BAKERY PRODUCTS
}

\section{ОСОБЛИВОСТІ ФОРМУВАННЯ КОНКУРЕНТОСПРОМОЖНОСТІ ПІДПРИЄМСТВ, ЩО СПЕЦІАЛІЗУЮТЬСЯ НА ВИРОБНИЦТВІ ХЛІБА ТА ХЛІБОБУЛОЧНИХ ВИРОБІВ}

UDC 339.137.2:664.64

https://doi.org/10.32843/infrastruct43-47

\section{Ryasnyanska Alona}

Candidate of Economic Sciences, Senior Lecturer at the Department of Business, Trade and Exchange Activity Petro Vasylenko Kharkiv National Technical University of Agriculture Kostanian Marine

Student

Petro Vasylenko Kharkiv National

Technical University of Agriculture

\begin{abstract}
The questions of formation of competitiveness of the enterprises specializing in the production of bread and bakery products are studied, as well as the current state, tendencies and problems of development of the baking industry in Ukraine. It is established that there is a tendency to decrease the production volume of bakery products in Ukraine. The leaders among the regions of Ukraine, namely, Dnipropetrovsk, Kyiv and Kharkiv regions, have been identified. It has been found that these products are not deficient at the moment, but studies indicate a strong shadow market segment that does not report to the departments of statistics. The factors of influence on the level of competitiveness of the baking industry are investigated, where the significant factors are the increase of prices for other foodstuffs, accessibility of purchase, marketing, advertising, positive image of the producer. In the example of Kharkiv region, the main competitors of the baking industry are investigated and the integral indicator of competitiveness for such enterprises is calculated.

Key words: competitiveness, level of competitiveness, enterprises specializing in the production of bread and bakery products, culture of nutrition, formation of competitiveness.
\end{abstract}

Изучены вопросы формирования конкурентоспособности предприятий, специализирующихся на производстве хлеба и хлебобулочных изделий, а также изучено современное состояние, тенденции и проблемы развития хлебопекарной отрасли в Украине. Установлено, что в Украине наблюдается тенденция к уменьшению объемов производства хлебобулочных изделий. Были выявлены лидеры среди регионов Украины, которыми оказались Днепропетровская, Киевская и Харьковская области. Было установлено, что в настоящее время эти продукты не являются дефицитными, но исследования указывают на появление мощного теневого сегмента рынка - предприятий, которые не отчитываются в отделах статистики. Исследованы фракторы влияния на уровень конкурентоспособности хлебопекарной отрасли, где значимыми фракторами являются рост чен на другие продукты питания, доступность закупок, маркетинг, реклама, позитивный имидж производителя. На примере Харьковской области исследованы основные конкуренты в хлебопекарной отрасли и рассчитан интегральный показатель конкурентоспособности для таких предприятий. Ключевые слова: конкурентоспособность, уровень конкурентоспособности, предприятия, специализирующиеся на производстве хлеба и хлебобулочных изделий, культура питания.

У статті проведено аналіз стану виробництва хліба та хлібобулочних виробів в Україні та в розрізі регіонів, зокрема проведено аналіз лідерів виробництва за регіонами. Встановлено, що спостерігається тенденція до зменшення обсягів виробництва хлібобулочних виробів в Україні. Виявлено лідерів серед регіонів України, якими виявились Дніпропетровська, Київська та Харківська обл. Виявлені причини зниження обсягів виробництва хліба та хлібобулочних виробів, виокремлено проблеми, що спостерігаються в хлібопекарській галузі та визначено шляхи їх вирішення. Порівнявши фрактичні дані Державної служби статистики України з реальним станом ринку хлібобулочних виробів, зроблено висновок, що обсяги виробництва хліба та хлібобулочних виробів зменшується в останні роки, проте насправді дефріциту продукції не спостерігається. Встановлено, що така ситуація склалася через появу потужного тіньового сегмента ринку: хліб продається в кіосках, зареєстрованих як ФОП або взагалі без реєстрації, які не подають звітність до відділів статистики; втрата виробничих потужностей внаслідок окупації частини території країни; багато супермаркетів в Україні спеціалізуються на випуску власної хлібопекарської продукції; випікання хлібобулочних виробів у домашніх умовах. Крім того, відмічено, що в останні роки змінилася культура споживання, на яку сильно вплинули ЗМІ, презентуючи хліб як висококалорійний продукт, корисність якого під сумнівом. Останнім часом світовим трендом є здоровий спосіб життя, який включає здорове, або як його прийнято називати «правильне» харчування, основою якого є зменшення вживання вуллеводів, вміст яких у хлібі перевищує норму. Досліджено характерні особливості фрормування конкурентоспроможності підприємств, що спеціалізуються на виробництві хліба та хлібобулочних виробів. Узагальнено аспекти впливу на рівень конкурентоспроможності таких підприємств, зокрема виділено такі зовнішні (соціальні, політико-правові, економічні) та внутрішні (сировинні ресурси підприємства, кадровий потенціал підприємства, маркетингова діяльність, стратегія підприємства, інноваційно-інвестиційна діяльність, територіальногеографрічне положення підприємства, виробнича діяльність, фрінансово-економічна діяльність). У роботі на прикладі Харківської області досліджено основних конкурентів хлібопекарської галузі і розраховано інтегральний показник конкурентоспроможності для цих підприємств. Ключові слова: конкурентоспроможність, рівень конкурентоспроможності, підприємства, які спеціалізуються на виробництві хліба і хлібобулочних виробів, культура харчування.

The problem formulation. Traditionally, bread and bakery products are of particular importance in the culture of the Ukrainian nutrition. These products consist about $40 \%$ of the total calorie content of the Ukrainian people's diet. The production of bread and bakery products belongs to the strategic branches of our country's economy since food and national security of the country depend on the efficiency of the performance of the enterprises that specialize in bread and bakery products. The social significance of bread, the need for stable and timely supply of qualitative and fresh produce to the population lead to the need to analyze the market for bread and bakery products, as well as to study the competitiveness of the enterprises that specialize in bread and bakery products. Actually, this study is dedicated to these issues.

Analysis of recent researches and publications. A number of scientific works of academic economists have been dedicated to the problems and prospects of the development of bread and bakery 
industry, in particular these issues have recently been considered by: Vasilchenko O.M., Hovorukha Zh.A., Hryshchenko A.M., Davydiuk Yu., Dziuba O.M., Drobot V.I., Rotated D.V., Kokovskaya S.I., Kostetska N.I., Litvinyuk O.P., Navolskaya N.V., Netyazhuk M.V., Obidina I.I., Oprah O.A., Prokip M.I., Repich T.A., Samilenko N.Y., Senishisha L.O., Strunin V.V., Teleshevskaya S.M., Urba S.I., Fedorova T.V., Filonenko T.M. and others. [1-9]. However, the bread and bakery industry is dynamic so that means it is constantly changing, developing, and it needs some further researches, and it is also strategically important to study the competitiveness of enterprises that specialize in bread and bakery products.

The statement of the article objectives. The purpose of this work is to analyze the state of bread and bakery production, as well as to study the peculiarities of the competitiveness of enterprises that specialize in bread and bakery products.

Research results. The study of condition, problems and prospects for development in bread and bakery market of Ukraine has been and will remain relevant in the future under any circumstances of country's economic development.

For a better understanding of "bread" situation in Ukraine, it is necessary to examine the statistical information of bakery production from 2010 to 2018 [10, p. 281].

Thus, there is a tendency of decreasing of bakery products production in Ukraine: from 1807700 tons in 2010 to 975100 tons in 2018 , that means that the production has fallen by $54 \%$ in comparison with 2010 . From 2010 to 2013 there was a gradual decrease in bakery products production, in 2013 flour production was 1561500 tons, and after 2013 there was a sharp decline: 1357100 tons in 2014, 1232000 tons in 2015, 1160000 tons in 2016, 1072600 tons in 2017 , 975100 tons in 2018 [10, p. 281] These changes stem from objective reasons: a production fall due to leaving of the Crimean peninsula territories, Donetsk and Luhansk regions, which significantly supported that field (its part in total bakery production in Ukraine in
2010 was $3,4 \%, 8.9 \%$ and $4.1 \%$ respectively) from the market. The loss of production capacities due to the occupation of a part of country's territories caused the geographical adjustment in bakery production.

Thus, according to the results of the first half of 2015 , bakery production in Donetsk region fell by $69.5 \%$ or 47500 tons. As a result, its part in the production fell by almost $6 \%$, and its position on ranking list got worse as it moved from the second to the eleventh place. In Luhansk region, the bakery production decreased almost by eight times. For the sake of clarity, the information about bread and bakery production of different regions is presented below (Fig. 2).

In 2018, the leaders among the Ukrainian regions were: Dnipropetrovsk region - 125800 tons, Kyiv region - 93800 tons and Kharkiv region - 73900 tons, Odesa region - 68400 tons, Zaporizhzhia region 50000 tons. The leaders in 2010 were: Dnipropetrovsk region - 186700 tons, Donetsk region - 161600 tons and Kharkiv regions - 131300 tons, Odesa region 93900 tons and Zaporizhzhia regions - 74800 tons [10, p. 281].

Ukraine produces over one million tons of bread and bakery products annually, which does not fully supply the Ukrainian population with these products, as bakery production: according to statistics of the State Statistics Service of Ukraine, there has been the amount of $23 \mathrm{~kg}$ per person in 2018, and the actual consumption of bakery production has been $100 \mathrm{~kg}$ per person [10, p. 99]. It is shown in the Table 1.

That is, the deviation of consumption over production is $(-77 \mathrm{~kg})$. And from 2010 to 2018, there was a decrease in bread production from 1807.7 thousand tons in 2010 to 975.1 thousand tons in 2018, together with the population decreased from 45963 thousand people to 42153 thousand persons, and, therefore, the value of the production indicator per person also decreased - from $39 \mathrm{~kg}$ per person to $23 \mathrm{~kg}$ per person. The actual consumption of bread also decreased: from $111 \mathrm{~kg}$ per person in 2010 to $100 \mathrm{~kg}$ per person in 2018. Production consumption deviations remain

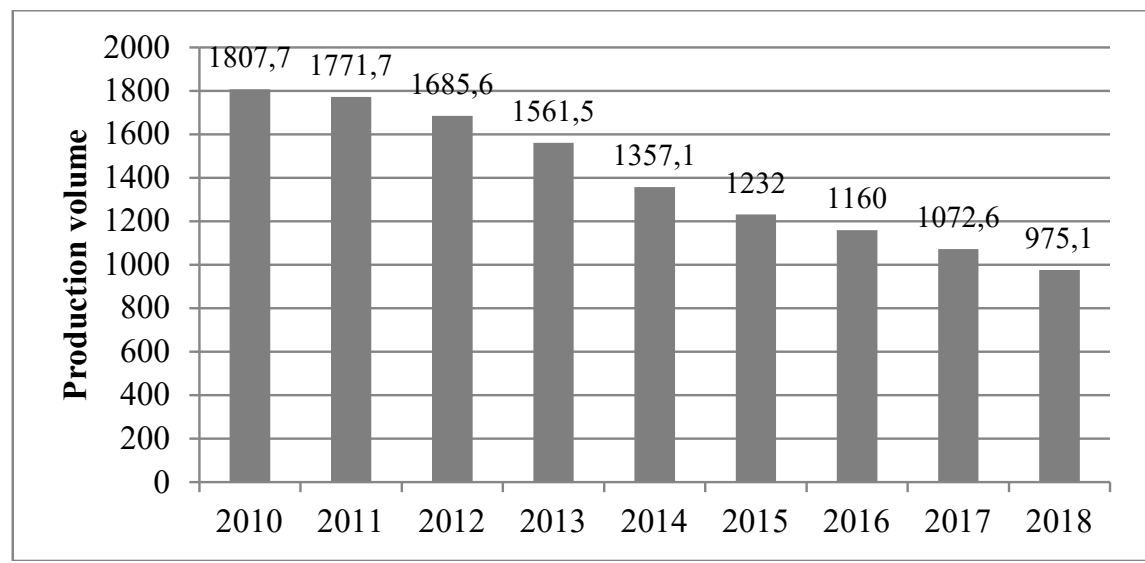

Figure 1. Dynamics of bread and bakery production in Ukraine in 2010-2018 
at approximately the same level: $-72 \mathrm{~kg}$ in 2010 , $-74 \mathrm{~kg}$ in 2015 and $-77 \mathrm{~kg}$ in 2018 [10].

Comparing the actual data of the State Statistics Service of Ukraine with the real state of the bakery products market, we can conclude that, in fact, there is no shortage of these products. This situation is due to the emergence of a strong shadow market segment: bread is sold in kiosks registered as sole proprietors or without registration at all. Due to this, they are able to reduce the cost of products, which are often made in insanitary conditions and cannot meet any quality standards. But as it is profitable, the shadow market segment accounts for about $60 \%$ of all bakery production. Such businesses do not report to statistical departments, which distorts the actual data. In addition, in recent years, one of the causes that led to the decline was the loss of production capacity due to the occupation of part of the country. Also, many supermarkets in Ukraine specialize in the production of their own bakery products, but this production is not fixed. And it is also necessary to consider baking of bakery products at home.
There are many factors that affect the competitiveness of businesses specializing in the production of bread and bakery products. Among which there are the external and internal factors [4, p. 2-5; 6, p.97-98]. To external factors we include:

- social (population, sex and age, food culture, income level);

- political and legal (legislative acts, political situation);

- economic (price, income level).

The internal include:

- raw material resources of the enterprise (availability of limited quality raw material resources of the enterprise; type of resource, cost and availability of the resource; market share of the enterprise as a production unit);

- personnel potential of the enterprise (structure and qualification of personnel; number of staff);

- marketing activities (availability of marketing service; availability of information and regulatory and methodological basis of management; image of the

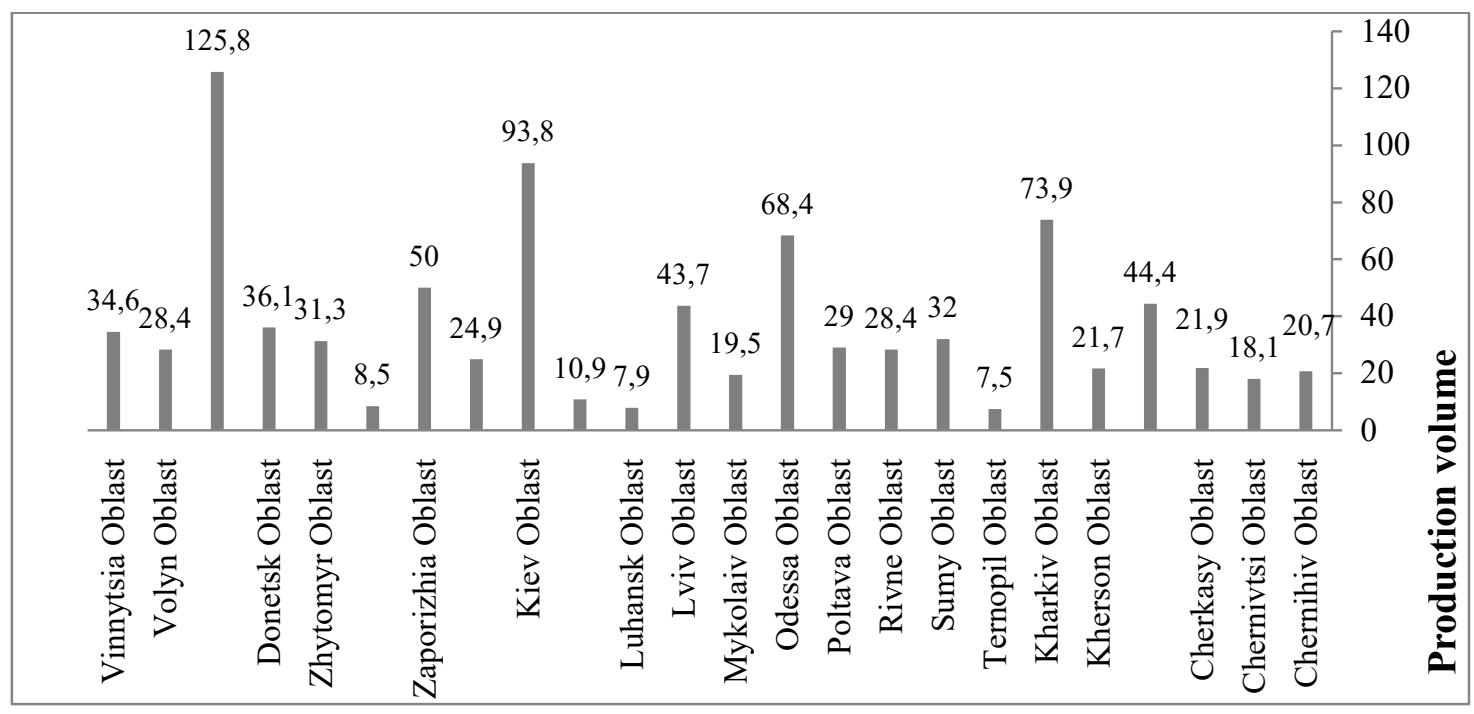

Fig. 2. Bread and bakery production by regions of Ukraine in 2018

Indicators of production and actual consumption

Table 1

of bread and bakery products in Ukraine from 2010 to 2018

\begin{tabular}{|c|c|c|c|c|c|}
\hline Year & $\begin{array}{c}\text { Bread production } \\
\text { (thousand tons) }\end{array}$ & $\begin{array}{c}\text { Population, } \\
\text { thousand people }\end{array}$ & $\begin{array}{c}\text { Production } \\
\text { for } \mathbf{1} \text { person, kg }\end{array}$ & $\begin{array}{c}\text { Actual consumption } \\
\text { of products } \\
\text { per person, kg }\end{array}$ & $\begin{array}{c}\text { Deviation +/- } \\
\text { (the production from } \\
\text { the consumption) }\end{array}$ \\
\hline $\mathbf{2 0 1 0}$ & 1807.7 & 45963 & 39 & 111 & -72 \\
\hline $\mathbf{2 0 1 1}$ & 1771.7 & 45779 & 39 & 100 & -61 \\
\hline $\mathbf{2 0 1 2}$ & 1685.6 & 45633 & 37 & 109 & -72 \\
\hline $\mathbf{2 0 1 3}$ & 1561.5 & 45553 & 34 & 108 & -74 \\
\hline $\mathbf{2 0 1 4}$ & 1357.1 & 45426 & 30 & 109 & -79 \\
\hline $\mathbf{2 0 1 5}$ & 1232.0 & 42929 & 29 & 103 & -74 \\
\hline $\mathbf{2 0 1 6}$ & 1160.0 & 42603 & 27 & 101 & -74 \\
\hline $\mathbf{2 0 1 7}$ & 1072.6 & 42485 & 25 & 101 & -76 \\
\hline $\mathbf{2 0 1 8}$ & 975.1 & 42153 & 23 & 100 & -77 \\
\hline
\end{tabular}


enterprise; sales opportunities to expand the geographical boundaries of the market; the presence of an extensive sales system; product quality);

- enterprise strategy (mission statement, longterm goals, paths and decision-making rules for the most effective use of strategic resources, strengths and opportunities, elimination of weaknesses);

- innovation and investment activities (number of research and production staff at the enterprise; costs of research, development and technological innovations; availability of cooperation with scientific units; possibility of profitable attraction of external financial resources; size of internal sources of financing);

- geographical location of the enterprise (access to raw materials; access to transport networks);

- production activity (features of applied technology and technology; level of mechanization and automation of labor; research activity; range, structure and quality of production);

- financial and economic activities (financial reporting standards used; solvency; profitability and profitability).

It should be noted that in recent years the culture of nutrition, which has been heavily influenced by the media, has changed, presenting bread as a highcalorie product, the usefulness of which is in doubt. Recently, the world trend is a healthy lifestyle, which includes healthy, or as it is called "proper" nutrition, the basis of which is to reduce the consumption of carbohydrates, the content of which exceeds the norm in bread. However, bread and bakery manufacturers have found an approach to such consumers by expanding their range to include non-yeast, gluten-free dietary bakery products. Expansion of the range helps to increase the demand and increase the competitiveness of enterprises specializing in the production of bread and bakery products. Today, we see a wide range of bread on the market, not including other bakery products: from "social" to "elite", different flavors - from different flour (wheat, rye, corn, buckwheat), with different additives (bran, raisins, raisins, dried apricots, nuts, sesame, poppy, cumin, fenugreek, hot pepper, sunflower seeds, pumpkin seeds, etc.), various shapes and sizes ("brick", loaf, baguette, mini-baguette, round meadow, pita), whole and half, or in slices. Even the most demanding consumer will find something to their taste.

An important factor for both producers and consumers is the price of bread and bakery products. Thus, according to statistics for January 2019, the most expensive bread was in Kyiv, and the cheapest was in the Odesa region. These data were obtained by the Retail Association of Ukraine by calculating the value of the bread basket. The bread basket included $1 \mathrm{~kg}$ of wheat bread from the highest grade flour, $1 \mathrm{~kg}$ of wheat bread from the first grade flour, $1 \mathrm{~kg}$ of rye bread and $0.5 \mathrm{~kg}$ of loaf. The most expensive regions were: Kyiv - $95 \mathrm{UAH}$ and Kyiv region - $81 \mathrm{UAH}$;
Zhytomyr region - 75 UAH; Zakarpattia - 73 UAH; Volyn region - $71 \mathrm{UAH}$. The "cheapest" regions are: Odesa region - $63 \mathrm{UAH}$; Mykolaiv region - $64 \mathrm{UAH}$; Dnipropetrovsk region - $65 \mathrm{UAH}$; Luhansk region $65 \mathrm{UAH}$; Ternopil region - $65 \mathrm{UAH}$. The intermediate position was occupied by: Donetsk and Cherkasy regions - 71 UAH each, Ivano-Frankivsk, Lviv and Khmelnitsky regions - $70 \mathrm{UAH}$ each, Kirovohrad, Poltava and Kherson regions - 69 UAH each, Zaporizhzhia, Sumy and Chernihiv regions - $68 \mathrm{UAH}$ each, Vinnytsia, Rivne and Kharkiv - $67 \mathrm{UAH}$ and Chernivtsi - 66 UAH [11]

Thus, by analyzing the state of bread production and the market of this industry, we can summarize the aspects of influence on the level of competitiveness of the bakery industry (Fig. 3) [17, p. 57-61].

We also emphasize the importance of organizing trade. Let us take this into the example of LLC "Kulinichi", which took a good position in the market, taking advantage of such important advantages as comfortable customer service, focusing on a particular consumer, where corporate trade plays a significant role. LLC "Kulinichi" has created a competitive environment in the bread and bakery industry, thereby displacing small businesses.

Today, the bread and bakery market is filled with products from different manufacturers. In 2017, the main representatives of the domestic bread market were such companies as Lauffer Group (Odessa Loaf, Donbasshlib, Khlibinvest) - 6.45\%, PJSC "Kyivhlib" - 6.42\%, LLC "Kulinichi" (Kyiv, Kharkiv) 4.73\%, PJSC "Concern Khlibprom" (Lviv, Vinnytsia region) - 3.33\%, LLC "Khlibodar" (Zaporizhzhia region) $-3.11 \%$ (Table 2) [12].

It is worth noting that the largest baking capacity in Ukraine is owned by the Lauffer Group. The average daily output of bakery products is 800 tons [16]. PJSC "Kyivhlib", a recognized leader of the Ukrainian bakery market, which includes 9 production sites in the capital and the Kyiv region, has a significant competitive position. At its own production capacity, the company produces 750 tons of bakery and 20 tons of pastry a day. Today the company's product range includes 700 items. LLC "Kulinichi", having taken the leading position among national bakeries, has established itself as a worthy producer of quality bread products. Today, the company includes 10 specialized baking complexes in Kharkiv, Kyiv and Poltava regions. The productivity of enterprises is 650 tons of bakery products per day [14]. In addition to large companies, the domestic bread and bakery market covers another 400 mini-bakeries with a capacity of 1 ton per year.

In the Kharkiv region, which is among the top three in the other regions of Ukraine in the production of bread and bakery products, the volume of bakery products in recent years has decreased from 112426 tons to 73870 tons in 2018 [15]. At the 
present stage, the competitiveness of enterprises specializing in the production of bread and bakery products is taking place to a greater extent, as explained above, due to such aspects as trade organization and assortment policy. For example, in the Kharkiv region, the leaders of bread production have traditionally been and remain LLC "Kulinichi" and LLC "Saltivsky", but in recent years the LLC "NovoBavarian Khlibzavod" and LLC "Roma" have entered the market (Pervomaisk, Kharkiv region). Also, in the bakery market, we can see such producers as: PJSC "Lyubotinsky Bakery", "Osnovyansky Bread". In addition to these enterprises in Kharkiv, you can buy products from neighboring regions, in particular, competitors in this field are the enterprises of LLC "Poltava-Khlib", LLC "Sumy Polyanytsia", and LLC "Riga Bread", Chernihiv. A powerful and main competitor of LLC "Kulinichi" at this time is LLC "Roma", although a few years ago, such competitor was LLC "Saltivsky", which was transferred to the management company "Korovaevo" for its debts. "Saltivsky" as well as LLC "Kulinichi" had its own trading network - booths with branded trade all over Kharkiv, which gradually began to disappear from the market in 2017 due to their financial situation. In 2018, among other players, the "bakery arena" was released by LLC "Roma", which is located in Pervomaisk in the Kharkiv region and even has establishments of corporate trade in this town, which, in addition to the main products, which are on the shelves of trade establishments of Kharkov, you can also buy additional bakery products (cakes, cookies, burgers, hot dogs, etc.).

Let us determine the current level of competitiveness of LLC "Roma" in the bakery market for further recommendations for its improvement. To do this, we propose to calculate an integral indicator of competitiveness, which takes into account such factors as: the price of products, the range of products, the duration of existence of the company, the design of packaging, the presence of a network of branded trade, advertising. To estimate the weighted values of these factors, we use a survey method, which was

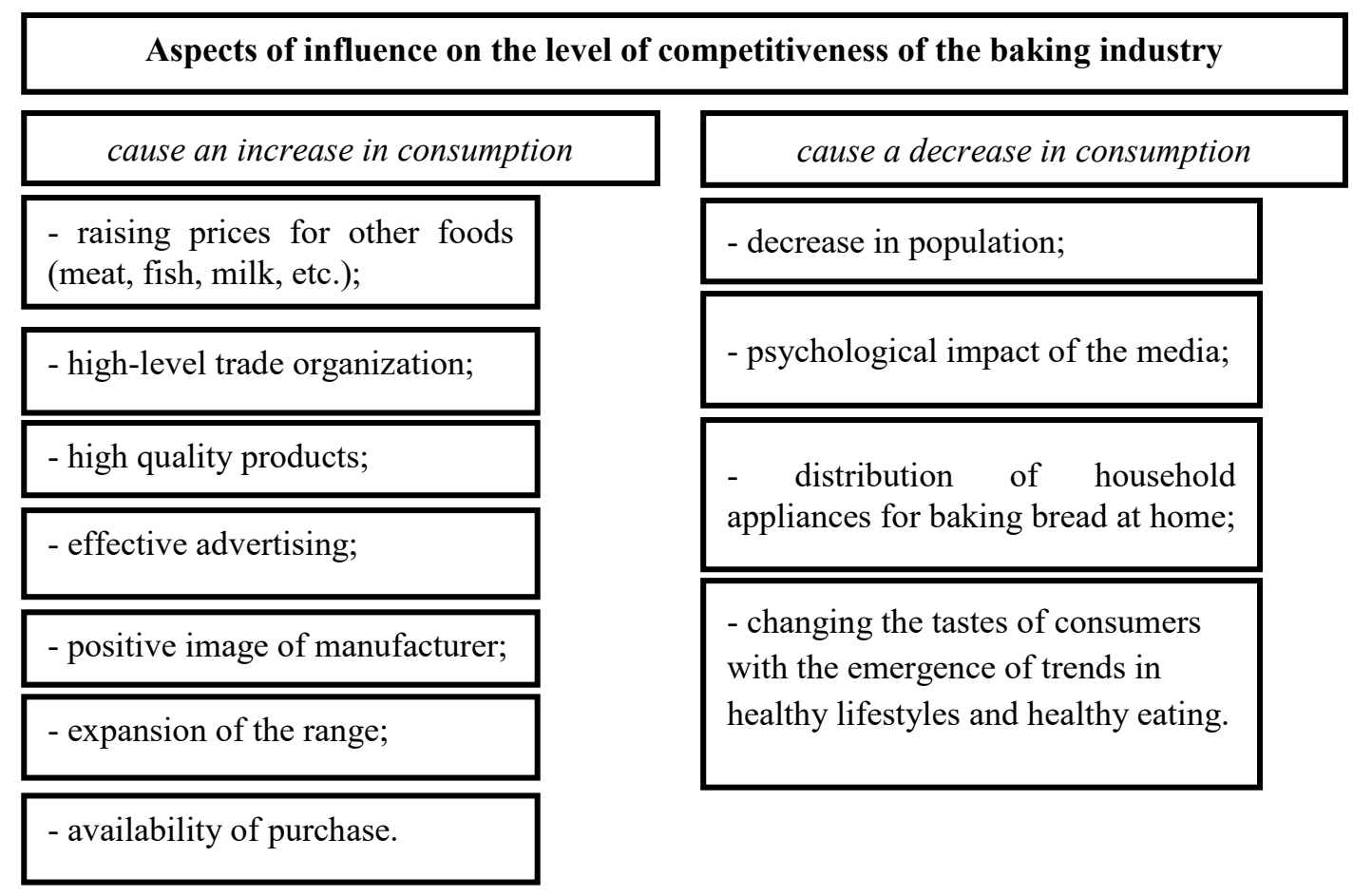

Fig. 3. Aspects of influence on the level of competitiveness of the baking industry

Table 2

The main participants in the bread and bakery market of Ukraine

\begin{tabular}{|c|c|c|}
\hline Supply chain & Number of participants & The main participants \\
\hline Production & $\begin{array}{c}\text { More than } 100 \text { bakeries and } \\
\text { over 400 mini-bakeries }\end{array}$ & $\begin{array}{c}\text { PJSC "Kyivkhlib", LLC "Khlibnilnvestitsii", JSC Concern "Khliboprom", } \\
\text { LLC "Kulinichi" Bakery, GK "Formula of taste", GK "Khlibodar", } \\
\text { Holding Gold Harvest Lauffer Group }\end{array}$ \\
\hline Wholesale & More than 100 participants & $\begin{array}{c}\text { LLC "August-Key", LLC "Athena Group", LLC "Tema-B", LLC "Hekta", } \\
\text { LLC "Alta Vista" }\end{array}$ \\
\hline Retail & \multicolumn{2}{|c|}{ Retail chains, supermarkets, shops, MAFs, food markets } \\
\hline End consumers & \multicolumn{2}{|c|}{ Population in Ukraine } \\
\hline
\end{tabular}


attended by 22 experts (business executives, experts in the baking industry, teachers in economic disciplines, etc.). Therefore, we can conclude by analyzing the experts' answers and rounding up the values in Table 3.

The competitiveness level of LLC "Roma" is estimated in comparison with LLC "Kulinichi", LLC "Saltivskyi", "Novo-Bavarian Khlibzavod" and LLC "Poltava-Khlib". For this purpose, experts were asked to evaluate the competitiveness factors of these enterprises on a 5-point scale (table 4).

Such factor as the duration of existence of the enterprise was estimated depending on the year of establishment of the company: LLC "Roma" - 1992, LLC "Kulinichi" - 1995, LLC "Saltivsky" - 2001, LLC "Novo-Bavarian Khlibzavod" - 1995 and LLC "Poltava-bread" - 2011. The factor "Availability of corporate trade network" was estimated as follows: LLC "Roma" - 4, LLC "Kulinichi" - 5, LLC "Saltivsky" - 4, LLC "Novo-Bavarian Khlibzavod" - 1, LLC "Poltava bread" - 1

We summarize the integrated value of the integrated indicator of competitiveness of the studied enterprises in Table 5.

As can be seen from table 5 , the highest value of the integral indicator of competitiveness is LLC "Kulinichi" 0.048, however, LLC "Roma" is not much
Weighting factors of the competitiveness of the baking industry enterprises obtained by the survey method

\begin{tabular}{|c|l|c|}
\hline № & Competitiveness factors & Weight value \\
\hline 1 & Product price & 0,4 \\
\hline 2 & Product range & 0,3 \\
\hline 3 & $\begin{array}{l}\text { Duration of existence } \\
\text { of the enterprise }\end{array}$ & 0,1 \\
\hline 4 & Packaging design & 0,05 \\
\hline 5 & $\begin{array}{l}\text { The presence of branded } \\
\text { network }\end{array}$ & 0,1 \\
\hline 6 & Advertising & 0,05 \\
\hline
\end{tabular}

lower than the value of this indicator 0.047. LLC "Saltivsky", LLC "Novo-Bavarian Khlibzavod" and LLC "Poltava-Khlib" have lower competitiveness indicators $-0.043,0.037$ and 0.033 . It means that LLC "Roma" can boldly expand the market and reach the level of the whole Kharkiv area with its branded trading network alongside LLC "Kulinichi".

Conclusions. As follows, the production of bread and bakery products in Ukraine is steadily declining. This trend continues in Kharkiv area. However, these data do not take into account the volume of baking at home, in small bakeries, supermarkets and households.

Table 4

Experts's results of the survey on the competitiveness factors of in the studied enterprises

\begin{tabular}{|c|c|c|c|c|c|c|c|c|c|c|c|c|c|c|c|c|c|c|c|c|}
\hline \multirow{3}{*}{ Experts } & \multicolumn{20}{|c|}{ Competitiveness factors } \\
\hline & \multicolumn{5}{|c|}{ the price of products } & \multicolumn{5}{|c|}{ product range } & \multicolumn{5}{|c|}{ packaging design } & \multicolumn{5}{|c|}{ advertising } \\
\hline & $\mathbf{R}$ & $\mathbf{K}$ & $\mathrm{s}$ & N-B & PB & $\mathbf{R}$ & $\mathbf{K}$ & $\mathbf{S}$ & N-B & PB & $\mathbf{R}$ & $\mathbf{K}$ & $\mathrm{S}$ & N-B & PB & $\mathbf{R}$ & $\mathbf{K}$ & $\mathbf{S}$ & N-B & PB \\
\hline 1 & 5 & 5 & 5 & 4 & 5 & 5 & 5 & 4 & 5 & 4 & 4 & 5 & 3 & 5 & 3 & 3 & 5 & 3 & 5 & 2 \\
\hline 2 & 5 & 5 & 5 & 3 & 4 & 5 & 5 & 5 & 4 & 4 & 5 & 5 & 4 & 3 & 4 & 3 & 5 & 4 & 4 & 3 \\
\hline 3 & 4 & 5 & 4 & 4 & 4 & 5 & 5 & 5 & 5 & 5 & 4 & 5 & 3 & 4 & 3 & 3 & 5 & 3 & 5 & 3 \\
\hline 4 & 5 & 5 & 5 & 5 & 4 & 5 & 5 & 5 & 4 & 3 & 5 & 5 & 5 & 5 & 4 & 4 & 5 & 3 & 4 & 2 \\
\hline 5 & 5 & 5 & 5 & 3 & 3 & 5 & 5 & 5 & 4 & 4 & 5 & 5 & 3 & 3 & 3 & 3 & 5 & 3 & 4 & 2 \\
\hline 6 & 4 & 5 & 4 & 4 & 5 & 5 & 5 & 5 & 5 & 3 & 5 & 5 & 3 & 4 & 4 & 4 & 5 & 4 & 5 & 3 \\
\hline 7 & 5 & 4 & 5 & 5 & 4 & 5 & 4 & 4 & 3 & 3 & 5 & 4 & 4 & 5 & 3 & 3 & 5 & 3 & 3 & 4 \\
\hline 8 & 5 & 5 & 5 & 3 & 5 & 4 & 5 & 5 & 4 & 4 & 5 & 5 & 3 & 4 & 3 & 3 & 4 & 3 & 4 & 2 \\
\hline 9 & 5 & 5 & 5 & 4 & 4 & 5 & 5 & 5 & 5 & 3 & 5 & 5 & 3 & 3 & 5 & 4 & 5 & 3 & 5 & 3 \\
\hline 10 & 4 & 5 & 5 & 3 & 4 & 4 & 5 & 5 & 3 & 3 & 5 & 5 & 4 & 4 & 4 & 4 & 5 & 3 & 3 & 2 \\
\hline 11 & 5 & 4 & 5 & 5 & 3 & 5 & 5 & 5 & 4 & 3 & 5 & 5 & 3 & 5 & 3 & 3 & 4 & 4 & 4 & 3 \\
\hline 12 & 5 & 5 & 5 & 3 & 5 & 4 & 5 & 5 & 3 & 5 & 5 & 5 & 3 & 4 & 4 & 3 & 5 & 3 & 5 & 2 \\
\hline 13 & 4 & 4 & 5 & 4 & 4 & 5 & 5 & 4 & 5 & 3 & 5 & 5 & 4 & 3 & 5 & 3 & 5 & 3 & 4 & 3 \\
\hline 14 & 5 & 5 & 4 & 3 & 4 & 5 & 5 & 5 & 4 & 3 & 5 & 5 & 3 & 5 & 3 & 3 & 5 & 3 & 3 & 2 \\
\hline 15 & 5 & 4 & 5 & 3 & 4 & 5 & 4 & 4 & 3 & 3 & 5 & 5 & 3 & 4 & 3 & 3 & 5 & 3 & 4 & 3 \\
\hline 16 & 5 & 5 & 5 & 5 & 4 & 4 & 5 & 5 & 5 & 3 & 5 & 5 & 3 & 3 & 4 & 4 & 5 & 3 & 5 & 3 \\
\hline 17 & 5 & 5 & 5 & 3 & 4 & 5 & 5 & 5 & 4 & 4 & 5 & 5 & 4 & 5 & 3 & 3 & 5 & 3 & 4 & 2 \\
\hline 18 & 5 & 5 & 5 & 5 & 5 & 5 & 5 & 5 & 3 & 3 & 5 & 5 & 3 & 4 & 4 & 4 & 5 & 4 & 3 & 3 \\
\hline 19 & 5 & 5 & 5 & 4 & 4 & 5 & 5 & 4 & 5 & 3 & 5 & 5 & 3 & 4 & 4 & 4 & 5 & 3 & 5 & 2 \\
\hline 20 & 5 & 5 & 5 & 4 & 3 & 5 & 5 & 5 & 4 & 5 & 5 & 4 & 3 & 5 & 3 & 3 & 5 & 3 & 4 & 3 \\
\hline 21 & 5 & 5 & 5 & 5 & 4 & 5 & 5 & 5 & 3 & 3 & 4 & 5 & 3 & 4 & 4 & 4 & 5 & 3 & 3 & 2 \\
\hline 22 & 5 & 5 & 5 & 4 & 4 & 5 & 5 & 5 & 4 & 3 & 5 & 4 & 3 & 5 & 3 & 3 & 5 & 3 & 5 & 2 \\
\hline $\begin{array}{c}\text { Summary } \\
\text { value }\end{array}$ & 4,8 & 4,8 & 4,9 & 3,9 & 4,1 & 4,8 & 4,9 & 4,8 & 4,0 & 3,5 & 4,9 & 4,9 & 3,3 & 4,1 & 3,6 & 3,4 & 4,9 & 3,2 & 4,1 & 2,5 \\
\hline
\end{tabular}


The summary of integrated values of the integrated indicator of competitiveness of the studied enterprises

\begin{tabular}{|c|c|c|c|c|c|c|c|}
\hline \multirow{4}{*}{ Enterprises } & \multicolumn{6}{|c|}{ Competitiveness factors } & \multirow{4}{*}{$\begin{array}{l}\text { An integral } \\
\text { indicator } \\
\text { of competi- } \\
\text { tiveness }\end{array}$} \\
\hline & $\begin{array}{l}\text { the price } \\
\text { of products }\end{array}$ & $\begin{array}{l}\text { product } \\
\text { range }\end{array}$ & $\begin{array}{l}\text { duration of } \\
\text { existence } \\
\text { of the } \\
\text { enterprise }\end{array}$ & $\begin{array}{l}\text { packaging } \\
\text { design }\end{array}$ & $\begin{array}{c}\text { availability } \\
\text { of branded } \\
\text { network }\end{array}$ & $\begin{array}{c}\text { availability } \\
\text { of branded } \\
\text { network }\end{array}$ & \\
\hline & \multicolumn{6}{|c|}{ Weight value } & \\
\hline & 0.4 & 0.3 & 0.1 & 0.05 & 0.1 & 0.05 & \\
\hline LLC "Roma" & 4.8 & 4.8 & 5 & 4.9 & 4 & 3.4 & 0.047 \\
\hline LLC "Kulinichi" & 4.8 & 4.8 & 4 & 4.9 & 5 & 4.9 & 0.048 \\
\hline LLC "Saltivsky" & 4.9 & 4.8 & 3 & 3.3 & 3 & 3.2 & 0.043 \\
\hline $\begin{array}{l}\text { LLC "Novo-Bavarian } \\
\text { Khlibzavod" }\end{array}$ & 3.9 & 4.0 & 4 & 4.1 & 1 & 4.1 & 0.037 \\
\hline LLC "Poltava Bread" & 4.1 & 3.5 & 2 & 3.6 & 1 & 2.5 & 0.033 \\
\hline
\end{tabular}

Based on the results of the analysis of the competitiveness of enterprises specializing in the production of bread and bakery products, it can be concluded that the decrease in volumes in Ukraine is due to such factors as: food culture, which is strongly influenced by the media, presenting bread as a highcalorie product, the usefulness of which is in doubt. Recently, the world trend is a healthy lifestyle, which includes healthy, or as it is called "proper" nutrition, the basis of which is to reduce the consumption of carbohydrates, the content of which exceeds the norm in bread. However, bread and bakery manufacturers should find an approach to such consumers by expanding the range to include non-dairy, gluten-free dietary bakery products, which will increase the competitiveness of such businesses.

So, the competitiveness of enterprises specializing in the production of bread and bakery products is taking place to a greater extent, as has been clarified, due to aspects such as trade organization and assortment policy.

Using the example of the Kharkiv region as the main competitors of the baking industry and calculating the integral competitiveness index, it has been found that LLC "Kulinichi" has the highest value of the integral competitiveness indicator 4.9, but LLC "Roma" is not much lower than this figure of 4.815. LLC "Saltivsky", LLC "Novo-Bavarian Khlibzavod" and LLC "PoltavaKhlib" have lower competitiveness indicators. It means that LLC "Roma" can boldly expand the market and reach the level of the whole Kharkiv region with its corporate trade network along with LLC "Kulinichi".

\section{REFERENCES:}

1. Dzyuba O.M. (2010) Formuvannya konkurentospromozhnosti pidpryyemstv khlibopekars'koyi haluzi [Formation of competitiveness of enterprises of baking science] (PhD Thesis), Vinnytsya.

2. Zavertanyy D.V. (2015) Suchasnyy stan ta perspektyvy rozvytku khlibopekars'koyi haluzi Ukrayiny [Current state and prospects of development of the baking orga- nization of Ukraine]. Market economy: modern management theory and practice. vol. 14. no. 2. pp. 194-203.

3. Kostets'ka N.I. (2015) Rynok khliba i khlibobulochnykh vyrobiv Ukrayiny: stan i perspektyvy rozvytku [Bread market and bakery products of Ukraine: state and prospects of development]. Galician economic journal. vol. 48. - no. 1. pp. 26-31.

4. Lytvynyuk O.P. (2013) Otsinka faktoriv konkurentospromozhnosti pidpryyemstv khlibopekars'koyi promyslovosti [Estimation of factors of competitiveness of the enterprises of the baking industry]. Available at: http://enuftir.nuft.edu.ua/jspui/bitstream/ 123456789/12372/1/1-8.pdf (accessed 30 April 2020).

5. Navol's'ka N.V. (2016) Doslidzhennya rynku khliba i khlibobulochnykh vyrobiv $v$ Ukrayini [Research of the market of bread and bakery products in Ukraine]. Global and National Problems of Economy. vol. 11. Available at: http://global-national.in.ua/archive/11-2016/93.pdf (accessed 30 April 2020).

6. Urba S.I., Kokovs'ka S.I. (2018) Upravlinnya konkurentospromozhnistyu pidpryyemstv khlibopekars'koyi haluzi [Management of competitive enterprises of the bakery organization]. Available at: http://www.visnyk-econom.uzhnu.uz.ua/archive/20_3_ 2018ua/22.pdf (accessed 30 April 2020).

7. Prokip M.I. (2013) Stan khlibopekars'koyi haluzi $v$ Ukrayini [The state of the bakery organization in Ukraine]. Available at: http://www.rusnauka.com/ 20_DNI_2013/Economics/9_14.doc.htm (accessed 30 April 2020).

8. Strunin V.V. (2014) Vitchyznyanyy rynok khlibobulochnykh vyrobiv: suchasnyy stan ta perspektyvy rozvytku [Domestic market of bakery products: current status and prospects]. Efektyvna ekonomika. no 12. Available at: http://www.economy.nayka.com.ua/ ?op $=1 \& z=3661$ (accessed 30 April 2020).

9. Fedorova T.V. (2015) Innovatsiyni pidkhody do upravlinnya konkurentospromozhnistyu pidpryyemstv khlibopekars'koyi haluzi [Innovative approaches to the management of competitive enterprises in the bakery industry]. Available at: http://ir.znau.edu.ua/handle/123456789/3298 (accessed 2 May 2020).

10. Verner I.Y. (ed.) (2018). Statystychnyy shchorichnyk Ukrayiny za 2018 r. [Statistical Yearbook of Ukraine for 2018], Zhytomyr: TOV "Buk-druk". 
11. Agricultural News Agency (2019) TOP-5 rehioniv z naydeshevshym i naydorozhchym khlibom [TOP-5 workers with the cheapest and most expensive bread]. Available at: https://agravery.com/uk/posts/show/ top-5-regioniv-z-najdesevsim-i-najdorozcim-hlibom (accessed 2 May 2020).

12. Antimonopoly Committee of Ukraine (2017) Zvit antymonopol'noho komitetu Ukrayiny za 2017 rik [Report of the Antimonopoly Committee of Ukraine for 2017]. Available at: https://drive.google.com/file/d/ 1Zp-gojNksXXfkf9rTtGMm4fQxf50jb27/view (accessed 2 May 2020).

13. Kyivkhlib (2020) Zahal'ni vidomosti pro kompaniyu [General information about the company]. Available at: http://kyivhlib.com.ua (accessed 2 May 2020).

14. Kulynychy (2020) Zahal'ni vidomosti pro kompaniyu [General information about the company]. Available at: http://www.kulinichi.com/ua (accessed 2 May 2020).

15. The Main Department of Statistics in Kharkiv Oblast (2020) Vyrobnytstvo promyslovoyi produktsiyi za vydamy za 2011-2018 roky [Production of an industrial company by type for 2011-2018]. Available at: http:// kh.ukrstat.gov.ua/vyrobnytstvo-osnovnykh-vydiv-promyslovoi-produktsii-schorichno (accessed 2 May 2020).

16. Latifundist.com (2020) Lauffer Group: vyrobnytstvo boroshna i khlibobulochnykh vyrobiv [Production of flour and bakery products]. Available at: https://latifundist.com/kompanii/535-lauffer (accessed 2 May 2020).

17. Lytvynyuk O.P. (2013) Osnovni chynnyky vplyvu na konkurentospromozhnist'pidpryyemstv khlibopekars'koyi haluzi [The main factors influencing the competitiveness of bakery enterprises]. Bulletin of Zaporizhzhia National University. Economic Sciences. no 2. pp. 56-62. Available at: http://nbuv.gov.ua/UJRN/ Vznu_eco_2013_2_11 (accessed 2 May 2020).

\section{БІБЛІОГРАФІЧНИЙ СПИСОК:}

1. Дзюба О.М. Формування конкурентоспроможності підприємств хлібопекарської галузі : авторефр. дис. ... канд. екон. наук : 08.00.04 «Економіка та управління підприємствами (за видами економічної діяльності)» ; Вінниця, 2010. 22 с.

2. Завертаний Д.В. Сучасний стан та перспективи розвитку хлібопекарської галузі України. Ринкова економіка: сучасна теорія і практика управління. 2015. Т. 14. Вип. 2. С. 194-203.

3. Костецька Н.І. Ринок хліба і хлібобулочних виробів України: стан і перспективи розвитку. Галицький економічний вісник. 2015. Т. 48. № 1. С. 26-31.

4. Литвинюк О.П. Оцінка фракторів конкурентоспроможності підприємств хлібопекарської промисловості. URL: http://enuftir.nuft.edu.ua/jspui/bitstream/ 123456789/12372/1/1-8.pdf (дата звернення: 30.04.2020).
5. Навольська Н.В. Дослідження ринку хліба і хлібобулочних виробів в Україні. Глобальні та національні проблеми економіки. 2016. Вип. 11. URL: http://global-national.in.ua/archive/11-2016/93.pdf (дата звернення: 30.04.2020).

6. Урба С.І., Коковська С.І. Управління конкурентоспроможністю підприємств хлібопекарської галузі. URL: http://www.visnyk-econom.uzhnu.uz.ua/archive/ 20_3_2018ua/22.pdf (дата звернення: 30.04.2020).

7. Прокіп М.І. Стан хлібопекарської галузі в Україні. URL: http://www.rusnauka.com/20_DNI_2013/ Economics/9_14.doc (дата звернення: 30.04.2020).

8. Струнін В.В. Вітчизняний ринок хлібобулочних виробів: сучасний стан та перспективи розвитку. Ефективна економіка. 2014. № 12. URL: http://dspace.nuft.edu.ua/jspui/bitstream/123456789/ 20728/1/Strunin_Filonenko.pdf (дата звернення: 30.04.2020).

9. Федорова Т.В. Інноваційні підходи до управління конкурентоспроможністю підприємств хлібопекарської галузі. Вісник Житомирського національного агроекологічного університету. 2015. № 1 (48), т. 2. С. $130-137$.

10. Статистичний щорічник України за 2018 р. / за ред. І.Є. Вернера. Житомир. ТОВ «Бук-друк», 2019. 482 c.

11. ТОП-5 регіонів 3 найдешевшим і найдорожчим хлібом. Аграрне інфрормаційне агентство : веб-сайт. URL: https://agravery.com/uk/posts/show/top5-regioniv-z-najdesevsim-i-najdorozcim-hlibom (дата звернення: 02.05.2020).

12. Звіт антимонопольного комітету України за 2017 рік. URL: https://drive.google.com/file/d/1ZpgojNksXXfkf9rTtGMm4fQxf50jb27/view (дата звернення: 02.05.2020).

13. Загальні відомості про компанію / ПАТ «КиївХліб» : веб-сайт. URL: http://kyivhlib.com.ua (дата звернення: 02.05.2020).

14. Загальні відомості про компанію / TM «Кулиничи» : веб-сайт. URL: http://www.kulinichi.com/ua (дата звернення: 02.05.2020).

15. Виробництво промислової продукції за видами за 2011-2018 роки / Головне управління статистики у Харківській області. URL: http://kh.ukrstat.gov.ua/ vyrobnytstvo-osnovnykh-vydiv-promyslovoi-produktsiischorichno (дата звернення: 02.05.2020).

16. LaufferGroup: виробництво борошна і хлібобулочних виробів. Latifundist.com : веб-сайт. URL: https://latifundist.com/kompanii/535-lauffer (дата звернення: 02.05.2020).

17. Литвинюк О.П. Основні чинники впливу на конкурентоспроможність підприємств хлібопекарської галузі. Вісник Запорізького національного університету. Економічні науки. 2013. № 2. С. 56-62. URL: http://nbuv.gov.ua/UJRN/Vznu_eco_2013_2_11 (дата звернення: 02.05.2020). 